\title{
Pathogenic and Genetic Characterization of Xanthomonas campestris Pv. campestris Races Based on Rep-PCR and Multilocus Sequence Analysis
} Priyanka Singh Rathaur ${ }^{1,2}$, Dinesh Singh ${ }^{1 *}$, Richa Raghuwanshi ${ }^{2}$ and Yadava DK $^{3}$

${ }^{1}$ Division of Plant Pathology, Indian Agricultural Research Institute, New Delhi-110012 India

${ }^{2}$ Department of Botany, Mahila Mahavidyalya ,Banaras Hindu University, Varanasi-221005, U.P, India

${ }^{3}$ Division of Genetics, Indian Agricultural Research Institute, New Delhi-110012, India

\begin{abstract}
Xanthomonas campestris pv. campestris (Pammel) Dowson (Xcc) is the causal agent of black rot disease of crucifers worldwide. Seventy five isolates of Xcc were collected from 12 agro-climatic regions of India to determine the distribution pattern of races and diversity of the population. Based on pathogenic reaction on seven standard differential crucifers, race $1,4 \& 6$ were found to be prevalent. For assessing the pathogenic diversity, forty one cultivars of crucifers comprising seven Brassica and coeno species were inoculated artificially under field conditions. Brassica juncea cultivars (Pusa Bold, Varuna, Pusa Vijay, Pusa Mustard 21 and Pusa Mustard 25) showed resistance against all the strains of Xcc, whereas the Brassica olerecea cultivar Pusa Ageti was found to be resistant to races 1 and 4. Genetic characterization of these 75 strains of Xcc was carried out using rep-PCR (ERIC, REP and BOXPCRs) followed by phylogenetic analysis. The strains of Xcc clustered into 6 groups at $50 \%$ similarity coefficient and among these groups, 28 strains of Xcc belonging to races $1,4 \& 6$ were clustered together under Group 5 . Sequences of the $16 \mathrm{~S} \mathrm{rRNA}, \mathrm{hrpF}$ and efP genes of five strains representing the races 1,4 and 6 were used for multilocus sequence analysis. Based on sequence analysis of $16 \mathrm{~S}$ rRNA and $h r p F$ genes, the Indian strains were found to be very closely related to the strain Xcc ATCC 33913 (race 3, UK), whereas based on efP sequences, they were found to be closely related to strains race 1 Xcc B100 (Italy) and race 9 Xcc 8004 (UK).
\end{abstract}

Keywords: Race; DNA fingerprinting; Diversity; 16S rRNA; hrpF; efP gene

\section{Introduction}

Black rot caused by Xanthomonas campestris pv. campestris (Pammel) Dowson (Xcc) is an important disease of crucifers, which substantially damages the crops by $10-50 \%$ under favourable environmental conditions. The pathogen infects a large number of cruciferous plants, including agriculturally important crops such as cole crops (broccoli, cabbage, cauliflower and knoll khol), turnip, radish, oliferous Brassica crops, ornamental plants, and weeds [1,2]. Based on the interaction of various strains of Xcc with different Brassica species, a total of nine pathogenic races of Xcc were established by using set of seven cultivars of crucifer [3-6]. Various molecular techniques such as RFLP patterns, repetitive sequence based PCR (rep-PCR), 16S rRNA gene analysis, $h r p$ (hypersensitive response and pathogenicity) gene and amplified fragment length polymorphism have been used to study the genetic variability among various bacteria [7-10]. Although, the PCR-based DNA-fingerprinting is a fast, reliable and comparatively low cost technique and its effectiveness depend on the primers chosen for analysis and the quality of the DNA. Three families of repetitive sequences (Rep) including repetitive extragenic palindromic (REP) sequences, Enterobacterial Repetitive Intergenic Consensus (ERIC) sequences, and the BOX element have been identified [11]. Studies of the 16S rRNA gene and the 16S-23S intergenic region are generally used to identify Xcc strains at the genus and species level. In Xcc, the $h r p$ cluster consists of 26 genes extending from $h p a 2$ to $h r p \mathrm{~F}$ [12] and among them the $h r p F$ gene is suitable for the differentiation of pathovars and used for diagnosis of Xanthomonas species [9,13,14]. Another gene efP encodes the elongation factor $\mathrm{P}$ protein that stimulates the peptidyl transferase activity of fully assembled $70 \mathrm{~S}$ prokaryotic ribosomes and enhances the synthesis of certain dipeptides initiated by $\mathrm{N}$-formylmethionine [15]. This gene has been used by [16] to study population genetic structure and diversity of Helicobacter pylori.
In order to design effective control strategies, especially seed health tests and development of resistant varieties against black rot disease, knowledge of the extent of genetic variability in the pathogen population is important. Thus, the variation within Xcc needs to be determined. In the present study, we collected 75 isolates of Xcc from black rot-infected cole crop and other crucifer crops from diverse agroclimatic regions of the country for assessing their race profile, virulence pattern of Xcc strains and their genetic diversity by using rep-PCR and multilocus sequence analysis using $h r p \mathrm{~F}, 16 \mathrm{~S}$ rRNA and efP genes of representative strains of Xcc races.

\section{Materials and Methods}

\section{Isolation of $X$. campestris pv. campestris}

Leaf samples (one or two plants from each field) exhibiting typical black rot symptoms of $\mathrm{V}$-shaped lesions with blackened veins were collected from major cole crops notably, cauliflower (Brassica oleracea var. botrytis L.), cabbage (B. oleracea var. capitata L.), knol-khol (B. oleracea var. gongylodes $\mathrm{L}$., and broccoli (B. oleracea var. italica Plenck), radish (Raphanus sativus L.), turnip (Brassica rapa var. rapa), Indian mustard [Brassica juncea (L.) Czerna and cross] and vegetable

*Corresponding author: Dinesh Singh, 1Division of Plant Pathology, Indian Agricultural Research Institute, New Delhi-110012, India, Tel: 91-9968246428; Fax 91-1125843113; E-mail: dinesh_iari@rediffmail.com

Received November 07, 2015; Accepted November 23, 2015; Published November 27, 2015

Citation: Rathaur PS, Singh D, Raghuwanshi R, Yadava DK (2015) Pathogenic and Genetic Characterization of Xanthomonas campestris Pv. campestris Races Based on Rep-PCR and Multilocus Sequence Analysis. J Plant Pathol Microbiol 6: 317. doi:10.4172/2157-7471.1000317

Copyright: @ 2015 Rathaur PS, et al. This is an open-access article distributed under the terms of the Creative Commons Attribution License, which permits unrestricted use, distribution, and reproduction in any medium, provided the original author and source are credited. 
Citation: Rathaur PS, Singh D, Raghuwanshi R, Yadava DK (2015) Pathogenic and Genetic Characterization of Xanthomonas campestris Pv campestris Races Based on Rep-PCR and Multilocus Sequence Analysis. J Plant Pathol Microbiol 6: 317. doi:10.4172/2157-7471.1000317

Page 2 of 9

mustard [B. juncea (L.) Czernajew] from 12 agro-climatic regions of India which covers major 18 states of India (Table 1). One or two leaf samples, representing one or two plants from each field, were selected for isolation of the causal agent from the typical V-shaped lesions. The diseased samples were dried between sheets of paper at room temperature before isolation of Xcc. From each leaf sample, 0.5 to $1 \mathrm{~cm}^{2}$ of leaf tissue was excised with a sterilised blade from the margin of a lesion. Then the excised leaf sections were sequentially passed through $70 \%$ alcohol for 20 seconds, $0.01 \% \mathrm{HgCl}_{2}$ for 20 seconds and twice in sterile distilled water for 40 seconds. Leaf sections were chopped with a sterile blade over sterile glass slides with few drops of distilled water and allowed to infuse for about $3 \mathrm{~min}$. Then a loopful of suspension was streaked on nutrient sucrose agar medium containing $23 \mathrm{~g}$ of nutrient

\begin{tabular}{|c|c|c|c|c|}
\hline S.No. & Agroclimatic Zones & States & Host & Isolates \\
\hline \multirow{7}{*}{1.} & \multirow{7}{*}{$\begin{array}{l}\text { Western Himalaya } \\
\text { Region }\end{array}$} & \multirow[b]{2}{*}{ Punjab } & Cabbage & Race 1- Xcc-C189 \\
\hline & & & Cauliflower & $\begin{array}{l}\text { Race 1- Xcc-C186, } \\
\text { Xcc-C187, Xcc- C188 }\end{array}$ \\
\hline & & \multirow[b]{2}{*}{$\begin{array}{l}\text { Jammu } \\
\text { Kashmir }\end{array}$} & Radish & Race-4-Xcc-C113 \\
\hline & & & Cauliflower & $\begin{array}{l}\text { Race-4- Xcc-C112, } \\
\text { Race 1- Xcc-C125, } \\
\text { Xcc-C126 }\end{array}$ \\
\hline & & \multirow{3}{*}{$\begin{array}{l}\text { Himachal } \\
\text { Pradesh }\end{array}$} & Cabbage & $\begin{array}{l}\text { Race 1-Xcc-C118, } \\
\text { Xcc-C205, Xcc-C206, } \\
\text { Xcc-C207 }\end{array}$ \\
\hline & & & Cauliflower & $\begin{array}{l}\text { Race 1- Xcc-C114, } \\
\text { Xcc-C128, Xcc-C210 }\end{array}$ \\
\hline & & & Radish & $\begin{array}{l}\text { Race 1- Xcc-C208, } \\
\text { Xcc-C209 }\end{array}$ \\
\hline \multirow{3}{*}{2.} & \multirow{3}{*}{$\begin{array}{l}\text { Eastern Himalaya } \\
\text { Region }\end{array}$} & \multirow{3}{*}{ Meghalaya } & Cabbage & Race 1- Xcc-C8 \\
\hline & & & Broccoli & Race 1- Xcc-C9 \\
\hline & & & Cauliflower & Race 1- Xcc-C119 \\
\hline 3. & $\begin{array}{l}\text { Lower Gangatic } \\
\text { Plains Regions }\end{array}$ & West Bengal & Cauliflower & $\begin{array}{l}\text { Race 4- Xcc-C197, } \\
\text { Xcc-C198 } \\
\text { Race 1- Xcc-C199, } \\
\text { Xcc-C200, }\end{array}$ \\
\hline \multirow{8}{*}{4.} & \multirow{8}{*}{$\begin{array}{l}\text { Middle Gangatic } \\
\text { Plains Regions }\end{array}$} & \multirow{4}{*}{$\begin{array}{l}\text { Uttar } \\
\text { Pradesh }\end{array}$} & $\begin{array}{l}\text { Indian } \\
\text { Mustard }\end{array}$ & Race 1- Xcc-C162 \\
\hline & & & Cabbage & $\begin{array}{l}\text { Race 4- Xcc- } \\
\text { C117, Xcc-C170 } \\
\text { Race 1- Хcc-C167 }\end{array}$ \\
\hline & & & Cauliflower & $\begin{array}{l}\text { Race 4- Xcc-C157, } \\
\text { Xcc-C195, Xcc-C196 } \\
\text { Race 1- Xcc-C161, } \\
\text { Xcc-C178 }\end{array}$ \\
\hline & & & Turnip & $\begin{array}{l}\text { Race 4- Xcc-C171 } \\
\text { Race 1- Xcc-C166 }\end{array}$ \\
\hline & & \multirow[b]{2}{*}{ Bihar } & Cabbage & Race 1- Xcc-C216 \\
\hline & & & Cauliflower & $\begin{array}{l}\text { Race 1- Xcc-C217, } \\
\text { Xcc-C218 }\end{array}$ \\
\hline & & \multirow[t]{2}{*}{ Jharkhand } & Cauliflower & $\begin{array}{l}\text { Race 4- Xcc-C111, } \\
\text { Race 1- Xcc-C131 }\end{array}$ \\
\hline & & & Cabbage & Race 1- Xcc-C130 \\
\hline \multirow{4}{*}{5.} & \multirow{4}{*}{$\begin{array}{l}\text { Upper Gangatic } \\
\text { Plains Regions }\end{array}$} & \multirow{4}{*}{ Uttrakhand } & Cauliflower & $\begin{array}{l}\text { Race 1- Xcc-C116, } \\
\text { Xcc-C120, } \\
\text { Race 4- Xcc-C227 }\end{array}$ \\
\hline & & & Knolkhol & $\begin{array}{l}\text { Race 4- Xcc-C219, } \\
\text { Xcc-C220 }\end{array}$ \\
\hline & & & Cabbage & $\begin{array}{l}\text { Race 4- Xcc-C221, } \\
\text { Xcc-C228 }\end{array}$ \\
\hline & & & $\begin{array}{l}\text { Indian } \\
\text { Mustard }\end{array}$ & Race 4- Xcc-C226 \\
\hline 6. & $\begin{array}{l}\text { Eastern Plateaus \& } \\
\text { Hill Region }\end{array}$ & Orissa & Cauliflower & $\begin{array}{l}\text { Race 4- Xcc-C127, } \\
\text { Xcc-C115 }\end{array}$ \\
\hline
\end{tabular}

\begin{tabular}{|c|c|c|c|c|}
\hline \multirow{9}{*}{7.} & \multirow{9}{*}{$\begin{array}{l}\text { Trans Gangatic } \\
\text { Plains Regions }\end{array}$} & \multirow{2}{*}{ Haryana } & Cabbage & Race 1- Xcc-C129 \\
\hline & & & Cauliflower & Race 4-,Xcc-C110 \\
\hline & & \multirow{7}{*}{ Delhi } & Cauliflower & $\begin{array}{l}\text { Race 1- Xcc-C23 } \\
\text { Race 4- Xcc-C147 }\end{array}$ \\
\hline & & & Broccoli & Race 1- Xcc-C4 \\
\hline & & & Cabbage & $\begin{array}{l}\text { Race 1- Xcc-C6 } \\
\text { Race 6- Xcc-C278, }\end{array}$ \\
\hline & & & Knol Khol & Race 1- Xcc-C14, \\
\hline & & & $\begin{array}{l}\text { Vegetable } \\
\text { Mustard }\end{array}$ & Race 1-Xcc-C16 \\
\hline & & & Turnip & Race 1-Xcc-C19 \\
\hline & & & $\begin{array}{l}\text { Indian } \\
\text { Mustard }\end{array}$ & Race 1- Xcc-C21 \\
\hline 8. & $\begin{array}{l}\text { Central Plateau \& Hill } \\
\text { Region }\end{array}$ & $\begin{array}{l}\text { Madhya } \\
\text { Pradesh }\end{array}$ & Cauliflower & $\begin{array}{l}\text { Race 1- Xcc-C230, } \\
\text { Xcc-C231 }\end{array}$ \\
\hline \multirow[b]{2}{*}{9.} & \multirow{2}{*}{$\begin{array}{l}\text { Southern Plateau \& } \\
\text { Hill Region }\end{array}$} & \multirow[b]{2}{*}{ Karnataka } & Cabbage & Race 1- Xcc-C124 \\
\hline & & & Cauliflower & $\begin{array}{l}\text { Race 1- Xcc-C132, } \\
\text { Xcc-C211, Xcc-C212, }\end{array}$ \\
\hline \multirow{2}{*}{10.} & \multirow{2}{*}{$\begin{array}{l}\text { West Coast plains \& } \\
\text { Hill Region }\end{array}$} & Maharashtra & Cauliflower & Race 1- Xcc-C248 \\
\hline & & Goa & Cauliflower & Race 1- Xcc-C247 \\
\hline \multirow[t]{2}{*}{11.} & \multirow{2}{*}{$\begin{array}{l}\text { Gujarat plains \& Hill } \\
\text { Region }\end{array}$} & \multirow[t]{2}{*}{ Gujarat } & Cabbage & $\begin{array}{l}\text { Race 4- Xcc- } \\
\text { C121,Xcc-C123 }\end{array}$ \\
\hline & & & Cauliflower & Race 1- Xcc-C122 \\
\hline 12. & Western Dry Region & Rajasthan & Cabbage & Race 1-Хcc-C190 \\
\hline
\end{tabular}

Table 1: List of Xanthomnas campestris pv. campestris strains isolated from crucifer crops, from different states, Host and races of India.

agar, $20 \mathrm{~g}$ of sucrose and $5 \mathrm{~g}$ of agar powder per liter and incubated at $28^{\circ} \mathrm{C}$ for $48 \mathrm{~h}$ [17]. Cultures were maintained in slants on YGCA medium for short times and for longer period cultures were stored at $-80^{\circ} \mathrm{C}$ with $50 \%$ glycerol in nutrient broth until further study.

\section{Pathogenicity tests}

Seventy five isolates of Xcc were tested for their pathogenicity on seedlings of a susceptible cultivar of cauliflower (cv. Pusa Sharad) which were grown under field conditions at the Indian Agricultural Research Institute, New Delhi. The inoculum of Xcc was prepared by culturing the bacteria on nutrient sucrose medium for forty-eight hours at $28^{\circ} \mathrm{C}$, then the bacterial growth was scraped from the Petri plates and suspended in sterile distilled water and inoculum of each isolates was maintained $0.1 \mathrm{OD}$ at $600 \mathrm{~nm}$ (U-2900 US/VJS spectrophotometer, model no. 2J1004, Hitachi) before inoculation as described by Singh et al. [2]. This bacterial suspension was inoculated with small scissors by dipping in the bacterial suspension and transferring onto the three youngest leaves of 30 days old plants with three replications as described by Vicente et al. [2]. The black rot disease reaction was recorded at 15 days after inoculation.

\section{Race characterisation}

Race characterisation of 75 strains of Xcc representing the diverse agro-climatic regions of India was achieved using a set of seven cultivars of Brassica species i.e., turnip (B. rapa var. rapa) 'Just Right Turnip F1' and 'Seven Top Turnip', Indian mustard (B. juncea (L.) Czernajew) 'Florida Broad Leaf', Ethiopian mustard (Brassica carinata L. Braun) 'PI 199947', rapeseed mustard (Brassica napus L) 'Cobra 14R', cauliflower (B. oleracea var. botrytis L.) 'Miracle F1' and cabbage (B. oleracea var. capitata L.) 'Wirosa F1' (Vicente et al. 2001; 2006). The seeds of these different lines were obtained from the University of Warwick, UK and from Otis S. Twilley Seed Co. Inc. (121 Gary Rd, Hodges SC 29653-9168 [B. juncea, B. rapa var. rapa EC732033 to EC732035]). Forty eight hour old cultures of the 75 strains of Xcc were pelleted and resuspended in sterilised distilled water to maintain an OD 0.1 at $600 \mathrm{~nm}$. The cultures 
were inoculated on to 35 days old plants of the cultivars Just Right Turnip F1, Seven Top Turnip, Florida Broad Leaf, PI 199947 and Cobra 14R; and plants of cultivars Miracle F1 and Wirosa F1 30 days after planting. Leaves were inoculated by clipping secondary veins, near the margins, with small scissors dipped in bacterial suspension. Ten points of inoculation were made in the youngest leaves on each plant with three replications. The number of infected points per leaf and the severity of symptoms were assessed after 15 and 30 days of inoculation. Based on the relative size of the largest lesion on the leaf, they were rated on a scale of $0-9$ as described by Vicente et al. [18].

\section{Pathogenic variability}

The pathogenic variability was studied during the winter season (November to March) for two consecutive years i.e., 2012-2013 and 2013-2014 at the Indian Agricultural Research Institute, New Delhi under field conditions by scoring disease reaction on the leaves of crucifers as given in Table 1 . A total of 41 representatives of the Crucifereae family including 7 economically important Brassica species i.e., B. campestris, B. carinata, B. juncea, B. napus, B. nigra, $B$. oleracea, and B. rapa and three Brassica coeno species (R. sativus, Eruca sativa and Sinapis alba) were tested against the 75 strains of Xcc, which are collected from diverse agroclimatic regions of India. All the 75 strains of Xcc were inoculated on 35 days old plants of turnip, radish and oliferous Brassica spp. and 30 days after planting of cole crops. Later the severity of symptoms was assessed as by described by Vicente et al. [18] In the present study, screening was carried out in the field during winter seasons, where temperature ranged from 7.2 to $30.1^{\circ} \mathrm{C}$ and rainfall ranged from 0 to $6.5 \mathrm{~mm}(2012-2014)$. Based on disease scores, the inoculated plants were grouped into four categories and the percentage of inoculated points showing symptoms as resistant, partially resistant, susceptible and highly susceptible were recorded as described by Vicente et al. [18].

\section{DNA extraction and molecular characterisation}

The strains of Xcc were grown in nutrient broth medium for $24 \mathrm{~h}$ at $28^{\circ} \mathrm{C}$. The total genomic DNA of the bacteria was extracted using the CTAB method [19]. Molecular characterisation of 75 isolates of Xcc was achieved using a $h r p F$ gene based PCR as described by Singh et al. [20].

\section{Genetic diversity by rep-PCR}

Genetic diversity of the 75 strains of Xcc was assessed by rep-PCR using the BOX, ERIC and REP. The primers and conditions were as described by Schaad et al. [17]. The data from rep-PCR (BOX, ERIC, REP-PCR) fingerprinting profiles were combined together to generate a similarity matrix by using the SIMQUAL module of NTSYSpc 2.02e. The similarity matrix was used for cluster analysis by unweighted pair group method of arithmetic average (UPGMA) using sequential, agglomerative, hierarchical, nested clustering module of NTSYSpc $2.02 \mathrm{e}[21]$. The output data are graphically presented as a phylogenetic tree.

\section{Multilocus sequence analysis}

Out of 75 strains, five strains representing three races of Xcc i.e., Xcc-C18 (race 1,turnip, Laxminagar, Delhi), Xcc-C131 (race 1, cauliflower, Ranchi, Jharkhand), Xcc-C168 (race 4, cabbage, Uttar Pradesh), Xcc-C106 (race 4, vegetable mustard, Laxminagar, Delhi) and Xcc-C278 (race 6, cabbage, Laxminagar, Delhi) were selected to study genetic variability by using $16 \mathrm{~S}$ rRNA, $h r p \mathrm{~F}$ and efP gene sequences. The primers for $16 \mathrm{~S}$ rRNA and efP gene amplification were designed using Primer 3 (www.frodo.wi.nit.edu) (Table 2) and checked for specificity in silico using www.insilico.ehu.es. The primers were validated for their universality across Xanthomonas and related bacteria by primer blasting using www.ncbi.nlm.nih.gov. About $25.0 \mu \mathrm{l}$ of PCR reaction mixture containing $5 \times$ Taq buffer $(5.0 \mu \mathrm{l}), 10 \mathrm{mM}$ dNTPs $(0.5$ $\mu \mathrm{l}), 25 \mathrm{mM} \mathrm{MgCl}_{2}(1.5 \mu \mathrm{l}), 10 \mu \mathrm{M}$ forward and reverse primers $(0.5 \mu \mathrm{l}$ each), Taq polymerase $(0.24 \mu \mathrm{l})$, molecular grade water and $1.0 \mu \mathrm{l} \mathrm{DNA}$ (100 ng) was used for PCR amplification. PCR was carried out under the following conditions using a Gradient thermocycler (C-1000TM, BIORAD): $95^{\circ} \mathrm{C}$ for two min followed by 30 cycles of $95^{\circ} \mathrm{C}$ for 30 seconds, annealing temperature and duration was varied according to gene (Table 2), $72^{\circ} \mathrm{C}$ for $1 \mathrm{~min}$ and terminated by a final elongation at $72^{\circ} \mathrm{C}$ for five min. The $h r p \mathrm{~F}$ gene primers and protocol used were as described by Singh et al. [20]. The PCR product was mixed with $1.0 \mu \mathrm{l}$ of loading dye. Electrophoresis was carried out using 1.2\% agarose gel, prepared in $1 \times$ Tris-acetate-EDTA (TAE) buffer containing ethidium bromide $\left(0.5 \mu \mathrm{g} \mathrm{ml}^{-1}\right)$. Electrophoresis was carried out at $60 \mathrm{~V}$ for 1.5 hours, visualised on a gel documentation system (BIORAD model Gel DocTM XR+) under UV light (300 nm) and photographed using image Lab version 2.0.1 software (BIORAD) for gel analysis. PCR products of the five strains were purified using Gel and PCR CleanUp kit (Promega). Sequencing was performed by Sanger's method (Applied Biosystem Machine-3130, Chromas Biotech, Bangalore, India). Sequence data of isolates were submitted to NCBI Genbank. For the $h r p \mathrm{~F}, 16 \mathrm{~S}$ rRNA and efP analysis, the sequences obtained were aligned pairwise. Multiple alignments compared to those of the type/ reference strains were performed with ClustalW (1.7) software [22] 994). Phylogenetic trees were generated using MEGA version 6.0 Tamura et al. [23] with default parameters, K2P distance model and the neighbour-joining algorithm (Saitou and Nei, [24]). Statistical support for tree nodes was evaluated by bootstrap (Felsenstein, $[25,26]$ ) analyses with 1,000 samplings.

\begin{tabular}{|c|c|c|c|c|}
\hline Locus & $\begin{array}{l}\text { Sequences of Primer } \\
\text { 5' - }\end{array}$ & Base pair (bp) & $\begin{array}{c}\text { Annealing temperature and } \\
\text { duration }\end{array}$ & Reference \\
\hline 16srDNA & $\begin{array}{l}\text { Xcc16S-F:5'-GCAAGCGTTACTCGGAATTA-3' } \\
\text { Xcc16S-R: 5'-TACGACTTCACCCCAGTCAT-3' }\end{array}$ & 959 & $56^{\circ} \mathrm{C}$ for $30 \mathrm{Sec}$ & Used in this study \\
\hline efP gene & $\begin{array}{l}\text { DXEP1F: 5'-TCATCACCGAGACCGAATA-3' } \\
\text { DXEP1R: 5'-TCCTGGTTGACGAACAGC-3' }\end{array}$ & 434 & $54^{\circ} \mathrm{C}$ for $30 \mathrm{Sec}$ & Used in this study \\
\hline hrp gene & $\begin{array}{c}\text { DhrpXccF:5'-GTGGCCATGTCGTCGACTC-3' DhrpXccR:5'- } \\
\text { GGAATAAACTGTTTCCCCAATG-3' }\end{array}$ & 769 & $60^{\circ} \mathrm{C}$ for $40 \mathrm{Sec}$ & Singh et al., 2014 \\
\hline BOX & BOXA1R: 5'-CTACGGCAAGGCGACGCTGACG-3' & Multiple bands & $53^{\circ} \mathrm{C}$ for $1 \mathrm{~min}$ & Schaad et al. 2001 \\
\hline ERIC & $\begin{array}{l}\text { ERIC1R: 5'-ATGTAAGCTCCTGGGGATTCAC-3' } \\
\text { ERIC2: 5'-AAGTAAGTGACTGGGGTGAGCG-3' }\end{array}$ & Multiple bands & $46^{\circ} \mathrm{C}$ for $1 \mathrm{~min}$ & Schaad et al. 2001 \\
\hline REP & $\begin{array}{l}\text { REP1R: 5'-IIIICGICGICATCIGGC-3' } \\
\text { REP21: 5'- ICGICTTATTATCIGGCCAC-3' }\end{array}$ & Multiple bands & $48^{\circ} \mathrm{C}$ for $1 \mathrm{~min}$ & Schaad et al. 2001 \\
\hline
\end{tabular}

Table 2: Primer used in this study. 
Citation: Rathaur PS, Singh D, Raghuwanshi R, Yadava DK (2015) Pathogenic and Genetic Characterization of Xanthomonas campestris Pv campestris Races Based on Rep-PCR and Multilocus Sequence Analysis. J Plant Pathol Microbiol 6: 317. doi:10.4172/2157-7471.1000317

\section{Results}

\section{Isolation of $X$. campestris pv. campestris}

Seventy-five strains of Xcc were isolated from eight major crops from diverse agro-climatic regions of India (Table 1). These isolates of Xcc produced yellow, translucent, raised, mucoid colonies on nutrient sucrose agar medium. They were found to be Gram-negative, rod shaped, aerobic with monotrichous flagella. Pathogenicity of all the isolates was tested on cauliflower (B. oleracea var. botrytis) cv. Pusa Sharad by artificial inoculation and all the isolates produced typical black rot disease symptoms of yellow or dead tissue at the edge of leaves, similar to tip burn, which frequently progressed into a $\mathrm{V}$-shape followed by blackening of the veins within 6-15 days of inoculation. These isolates were considered to be Xcc on the basis of these morphological and pathogenicity tests. For further confirmation, these isolates were tested by PCR amplification using the primers Dhrp_Xcc_F and Dhrp_Xcc_R, which generate a $769 \mathrm{bp}$ product and they were specific to Xcc. The strains of Xcc caused black rot, are morphologically indistinguishable and yielded a $769 \mathrm{bp}$ PCR amplification product. These data confirmed them as the causal agent of black rot disease prior to further pathogenic and genomic diversity analysis.

\section{Race characterisation}

In the present study, a set of seven selective cultivars of Brassica species were used for the race profiling of 75 strains of Xcc. Three races i.e., races 1, 4 and 6 were found in the Indian Xcc strains. Xcc strains which showed positive disease reactions in 5 cultivars [Wirosa F1 ( $B$. oleracea), Just Right Hybrid Turnip (B. rapa), line 14R of Cobra ( $B$. napus), PI 199947 (B. carinata) and Florida Broad Leaf Mustard (B. juncea)] were designated as race 1 strain. Race 4 showed positive disease reactions on only 2 cultivars i.e., Wirosa $\mathrm{F} 1$ (B. oleracea var. capitata) and Miracle F1 (B. oleracea var. botrytis)), whereas race 6 showed positive reactions in all seven cultivars. Out of 75 strains of Xcc, 51 strains belonged to race 1 (68\%), 23 strains belonged to race $4(31 \%)$ and a single strain Xcc-C278 belonged to race $6(1 \%)$. The Race 6 Xcc strain was isolated from infected leaves of cabbage (Delhi), while race 1 and race 4 strains were isolated from infected leaves of cauliflower, cabbage, broccoli, knol khol, turnip, radish, Indian mustard, vegetable mustard and black mustard. Besides these, race 1 and race 4 Xcc also infected kale and Brussels sprouts respectively.

\section{Pathogenic variability}

Pathogenic variability of Xcc was tested in two cropping seasons on 41 cultivars of crucifers including seven Brassica spp, namely $B$. campestris, B. carinata, B. juncea, B. napus, B. nigra, B. oleracea and $B$. rapa, and three Brassicas coeno species, namely R. sativus, E. sativa and S. alba. Based on the pathogenicity profiles of the 75 strains of Xcc, $B$. juncea cultivars (Cv. Pusa Bold, Varuna, Pusa Vijay, Pusa Mustard 21 and Pusa Mustard 25) showed resistance to all the races of Xcc (Table 3). However, Pusa Ageti (cabbage) showed resistant to races 1 and race 4 only. Pusa Swarnim, a cultivar of B. carinata, and Pusa Swarnima, a cultivar of $B$. rapa var. rapa were moderately resistant to race1, whilst the Bhawani cultivar of $B$. rapa cv. toria was moderately resistant to races 1 and 4 (Table 3). Among these races, race 1 dominated in all 12 agro-climatic regions of India and occurred in most of the indian states except Orissa, whereas race 4 did not occur in Punjab, Himachal Pradesh, Bihar, Madhya Pradesh, Meghalaya, Maharashtra, Goa and Rajasthan states.

\section{Genetic diversity by rep-PCR}

The patterns from the rep-PCR of all investigated strains consisted

\begin{tabular}{|c|c|c|c|c|}
\hline \multirow[t]{2}{*}{ Species of crucifers } & \multirow[t]{2}{*}{$\begin{array}{l}\text { Common name } \\
\text { (cultivars) }\end{array}$} & \multicolumn{3}{|c|}{$\begin{array}{l}\text { Disease Reaction of } X . \\
\text { campestris pv. campestris } \\
\text { races on crucifer host }\end{array}$} \\
\hline & & $\begin{array}{l}\text { Race1 } \\
(51)\end{array}$ & $\begin{array}{l}\text { Race } 4 \\
(23)\end{array}$ & $\begin{array}{c}\text { Race } 6 \\
\text { (1) }\end{array}$ \\
\hline Brassica juncea & $\begin{array}{l}\text { Indian Mustard (Pusa } \\
\text { Bold) }\end{array}$ & $\mathrm{R}$ & $\mathrm{R}$ & $\mathrm{R}$ \\
\hline B. juncea & Varuna & $\mathrm{R}$ & $\mathrm{R}$ & $\mathrm{R}$ \\
\hline B. juncea & Pusa Vijay & $\mathrm{R}$ & $\mathrm{R}$ & $\mathrm{R}$ \\
\hline B. juncea & Pusa Mustard-21 & $\mathrm{R}$ & $\mathrm{R}$ & $\mathrm{R}$ \\
\hline B. juncea & Pusa Mustard-25 & $\mathrm{R}$ & $\mathrm{R}$ & $\mathrm{R}$ \\
\hline B. napus & GSL-1 & $\mathrm{s}$ & $s$ & $\mathrm{~s}$ \\
\hline B. napus & GSL-2 & S & S & S \\
\hline B. napus & GSL-5 & S & S & S \\
\hline B. napus & PAC-401 & $\mathrm{S}$ & S & S \\
\hline B. carinata & (Pusa Swarnim) IGC-01 & MR & S & S \\
\hline B. carinata & (Pusa Aditya) NPC-9 & $S$ & S & S \\
\hline B. carinata & $\mathrm{HC}-2$ & s & S & S \\
\hline B. carinata & Kiran & S & S & S \\
\hline B.rapa cv.toria & Bhawani & $S$ & S & S \\
\hline B.rapa cv.toria & Pt-303 & MR & $\mathrm{s}$ & S \\
\hline B.rapa cv.toria & TL-15 & $\mathrm{S}$ & S & S \\
\hline B.rapa cv.toria & T-9 & $\mathrm{s}$ & $\mathrm{s}$ & $\mathrm{s}$ \\
\hline B.rapa subsp. sarson & Pusa Kalyani & $\mathrm{s}$ & $\mathrm{s}$ & $\mathrm{s}$ \\
\hline B.rapa subsp. sarson & BSH-1 & $\mathrm{s}$ & $\mathrm{s}$ & $\mathrm{s}$ \\
\hline B.rapa subsp. sarson & BSH-9 & $\mathrm{s}$ & $\mathrm{s}$ & $\mathrm{s}$ \\
\hline B.rapa subsp. tricularis & PBT-37 & $\mathrm{s}$ & $\mathrm{s}$ & $\mathrm{s}$ \\
\hline B.rapa subsp. sarson & Pusa Gold & S & S & S \\
\hline B.rapa subsp. sarson & YSH-0401 & S & S & S \\
\hline B.rapa subsp. sarson & NIC-394 & S & S & S \\
\hline Sinapis alba & IC-390162 & S & S & s \\
\hline Eruca sativa & RTN-314 & $\mathrm{S}$ & $\mathrm{s}$ & $\mathrm{s}$ \\
\hline E. sativa & $\mathrm{T}-27$ & S & $S$ & $S$ \\
\hline B. nigra & IC-247 & S & s & s \\
\hline B.nigra & SRB-9 & s & s & $\mathrm{S}$ \\
\hline B.oleracea var. capitata & $\begin{array}{l}\text { PusaAgeti } \\
\text { (cabbage) }\end{array}$ & $\mathrm{R}$ & $\mathrm{R}$ & $\mathrm{s}$ \\
\hline B.oleracea var. capitata & B. oleracea (cabbage) & S & S & $\mathrm{S}$ \\
\hline B. oleracea var. botrytis & $\begin{array}{l}\text { Pusa Sharad } \\
\text { (cauliflower) }\end{array}$ & s & $S$ & $\mathrm{~s}$ \\
\hline B. oleracea var. botrytis & B.o (cauliflower) & $\mathrm{s}$ & $\mathrm{s}$ & $\mathrm{s}$ \\
\hline $\begin{array}{l}\text { B. oleracea var. } \\
\text { gongylodes }\end{array}$ & $\begin{array}{l}\text { PalamTender } \\
\text { (knol khol) }\end{array}$ & s & s & $\mathrm{s}$ \\
\hline B. rapa var. rapa & Pusa Swarnima (Turnip) & MR & S & $\mathrm{R}$ \\
\hline B. rapa var. rapa & Pusa Swati (Turnip) & $S$ & S & $\mathrm{S}$ \\
\hline R. sativus & Radish(Pusa Deshi) & S & S & S \\
\hline R. caudatus & R. caudatus & s & S & $\mathrm{S}$ \\
\hline $\begin{array}{l}\text { Brassica oleracea var. } \\
\text { gemmifera }\end{array}$ & $\begin{array}{l}\text { Brussel Sprout } \\
\text { (E-220 NANO) }\end{array}$ & s & s & $\mathrm{s}$ \\
\hline B. juncea & Pusa Sag & $\mathrm{R}$ & $\mathrm{R}$ & $\mathrm{R}$ \\
\hline Camellina sativa & Camellina sativa & $S$ & $\mathrm{~s}$ & S \\
\hline
\end{tabular}

Group A: (Race 1) Xcc-C189, Xcc-C186, Xcc-C187, Xcc-C188, Xcc-C125, Xcc C126,Xcc-C118, Xcc-C205, Xcc-C206, Xcc-C207,Xcc-C114, Xcc-C128, Xcc-C210 ,Xcc-C208, Хcc-C209, Хcc-C8, Хcc-C9,Хcc-C119, Хcc-C199, Хcc-C200, Xcc-C162, Xcc-C167, Xcc-C161, Xcc-C178, Xcc-C166, Xcc-C216, Xcc-C217, XccC218, Xcc-C131, Хcc-C130, Хcc-C116, Хcc-C120, Хcc-C129, Хcc-C23, Хcc-C4 Xcc-C6 , Хcc-C14, Хcc-C16, Хcc-C19, Хcc-C21, Хcc-C230, Xcc-C231, Хcc-C124, Xcc-C132, Xcc-C211, Xcc-C212, Xcc-C248, Xcc-C247, Xcc-C122, Xcc-C190

Group B: (Race 4) Xcc-C113, Xcc-C112,Xcc-C197, Xcc-C198, Xcc-C117, XccC170,Xcc-C157, Xcc-C195, Xcc-C196, Xcc-C171, Xcc-C111, Xcc-C227 Xcc-C219, Xcc-C220,Xcc-C221, Хcc-C228 Xcc-C226, Хcc-C127, Хcc-C115, Хcc-C110, Xcc-C147, Xcc-C121,Xcc-C123

Group C: (Race 6) Xcc-C278

Table 3: Pathogenic reaction of crucifer cultivars against $X$. campestris pv. campestris strain under field condition. R-Resistant Reaction, MR-Moderately Resistant, S- Susptible Reaction. 
Citation: Rathaur PS, Singh D, Raghuwanshi R, Yadava DK (2015) Pathogenic and Genetic Characterization of Xanthomonas campestris Pv campestris Races Based on Rep-PCR and Multilocus Sequence Analysis. J Plant Pathol Microbiol 6: 317. doi:10.4172/2157-7471.1000317

of 3 to 10 fragments ranging in size from approximately 0.3 to $7 \mathrm{~kb}$. Amplification profiles of each strain of Xcc varied between all three methods of PCR as 3-9 amplicons were obtained in the REP-PCR, 8-14 in ERIC and 10-16 in BOX-PCR (Figure 1).

Computer assisted analysis of rep-PCR profiles showed a very high level of diversity among the Xcc strains. All the strains of Xcc could be clustered into 6 groups at $50 \%$ similarity coefficient. In these groups, Group 1, 2 and 5 contained 21, 12 and 28 strains of Xcc and these strains were further clustered at $75 \%$ similarity co-efficient into 20 subgroups (Figure 2). Group I was further divided in to six subgroups (IA, IB, IC, ID, IE and IF), group II divided into five subgroups (IIA, IIB, IIC, IID, IIE) and group V in to three subgroups (VA, VB and VC). Group 3 and 4 contained 10 and 3 strains respectively. Group III was further clustered into two subgroups (IIIA, IIIB) and group IV was divided into three subgroups (IVA, IVB and IVC). Group 6 contained the single isolate Xcc-C1. The 28 strains of Xcc found in group 5 were found to belong to races 1,4 and 6 . This reveals the existence of diversity among Xcc strains, which represent the diverse agro-climatic regions of India.

\section{Multilocus sequence analysis}

Three different genetic loci, i.e., $h r p \mathrm{~F}, 16 \mathrm{~S}$ rRNA and efP genes, were used separately to study the genetic diversity among five strains of Xcc representing races 1, 4 and 6 . DNA sequence analysis of $16 \mathrm{~S}$ rRNA and the 16S-23S intergenic regions has revealed a much greater diversity than previously recognised among strains leading to important revisions in the taxonomy and systematics of xanthomonads $[8,25]$. The partial nucleotide sequences of the $16 \mathrm{~S}$ rRNA of four strains of Xcc i.e., Xcc-C18 (race1, turnip), Xcc-C106 (race 4, vegetable mustard), Xcc-C131 (race 1, cauliflower) and Xcc-C168 (race 4, cabbage) and Xcc-C278 (race 6, cabbage) showed more than $99.8 \%$ identity to each other and they were very closely related to Xcc strain ATCC 33913 (Race 3, Brussels sprout, UK as earlier reported by Popovic et al. [27]. These strains also showed more than $99.8 \%$ identity with $X$. arboricola pathovars glycines, punicae, poinsettiicola LMG 8676, X. campestris pv. viticola and X. campestris LMG 5793, X. citri subsp. citri Aw12879, X. gardneri DSM 19127 (bacterial leaf spot disease of tomato), X. meloni, X. dye 12167 and X. populi. (Figure 3). Our result finding was corroborative with the result obtained by Popovic et al. [27].

The efP gene sequence analysis of the representative Indian Xcc isolates showed high similarity identity matrix $(>98 \%)$ among each other and were very closely related to the sequence of strains Xcc B100 (race 1) and Xcc 8004 (race 9). However, the sequence of Xcc strain ATCC 33913 (race 3), was distinct from those of other strains of Xcc (Figure 4) but showing more than $95 \%$ with identity $X$. campestris pv. rapahani $756 \mathrm{C}, X$. campestris pv. vesicatoria and $X$. axonopodis pv. citrumelo. For genetic diversity assessment, the efP gene was earlier used by Achtman et al. [16] to study the population genetic structure and diversity of $H$. pylori, which revealed about $85 \%$ relatedness for strains from different geographical regions. Based on their ef $\mathrm{P}$ sequences, all the Xcc isolates analysed here grouped in the same cluster (Group 1 and Figure 4), except Xcc ATCC 33913 so this phylogenetic analysis

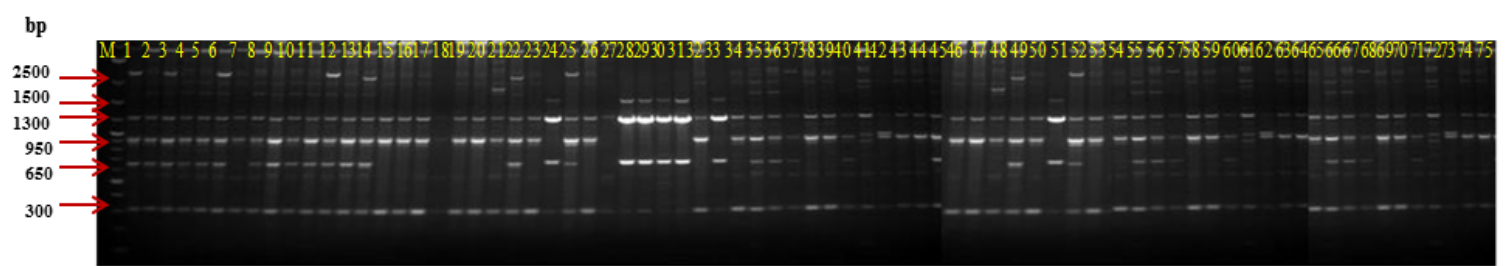

Fig. la. Box Fingerprints

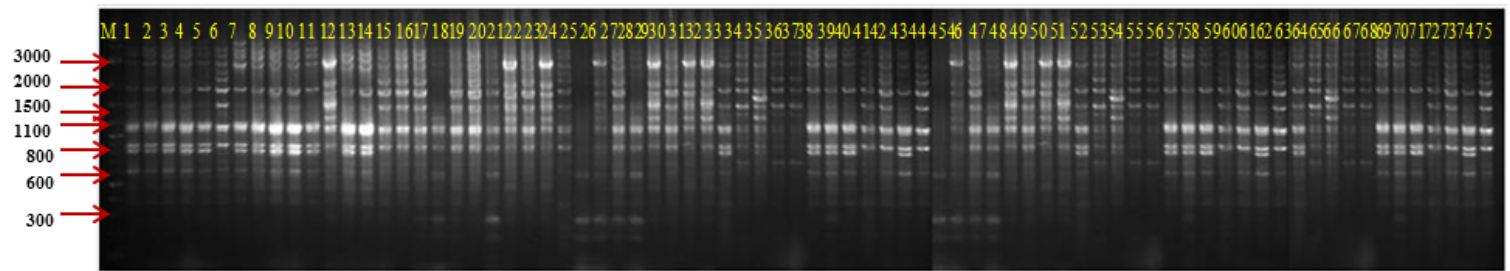

Fig.1b. ERIC Fingerprints

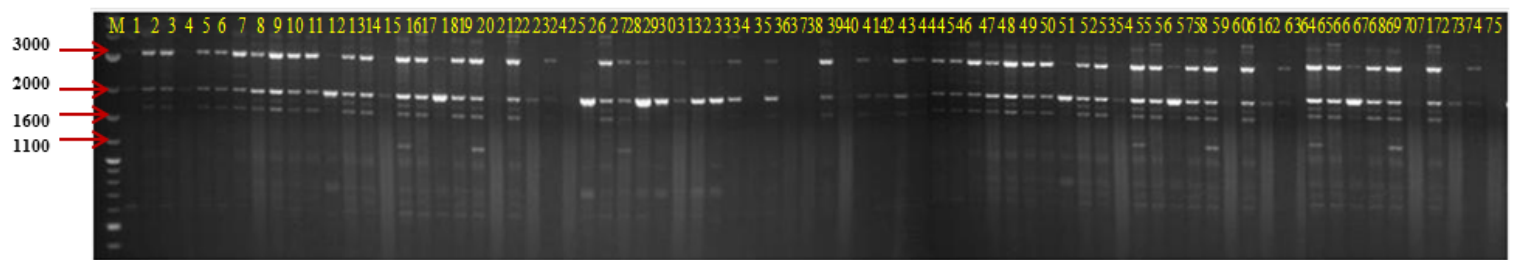

Fig. 1c. REP Fingerprint

Lane M: 1.0 Kb DNA ladder, lanes 1-75: Xcc-C4, Xcc-C6, Xcc-C8, Xcc-C9, Xcc-C14, Xcc-C16, Xcc-C19, Xcc-C21, Xcc-C23, Xcc-C110, Xcc-C111, Xcc-C112, Xcc-C113, Xcc-C114, Xcc-C115, Xcc-C116, Xcc-C117, Xcc-C118, Xcc-C119, Xcc-C120, Xcc-C121, Xcc-C122, Xcc-C123, Xcc-C124 Xcc-C125, Xcc-C126, Xcc-C127, Xcc-C128, Xcc-C129, Xcc-C130, Xcc-C131, Xcc-C132, Xcc-C147, Xcc-C157, Xcc-C161, Xcc-C162, Xcc-C166, Xcc-C167, Xcc-C170, Xcc-C171, Xcc-C178, Xcc-C185, Xcc-C187, Хcc-C186, Хcc-C187, Xcc-C188, Xcc-C189, Xcc-C190, Хcc-C195, Xcc-C196, Xcc-C197, Xcc-C198, Xcc-C199, Xcc-C200, Xcc-C205, Xcc-C206, Xcc-C207, Xcc-C208, Xcc-C209, Хcc-C210, Xcc-C211, Xcc-C212, Xcc-C216, Xcc-C217, Xcc-C227, Xcc-C228, Xcc-C230, Xcc-C231, Xcc-C247, Xcc-C248, Xcc-C278, Xcc-C218, Xcc-C219, Xcc-C220, Xcc-C221, Xcc-C221, Xcc-C226,

Figure 1: Larvicidal activity of Callicarpa americana leaf extracts against fourth instar larvae of Aedes albopictus at various concentrations. Percent mortality was determined 24 hours after treatment. Mosquitoes that were non-responsive to physical stimulation were counted as dead. Error bars represent the standard error of the mean of three independent assays. 
Citation: Rathaur PS, Singh D, Raghuwanshi R, Yadava DK (2015) Pathogenic and Genetic Characterization of Xanthomonas campestris Pv campestris Races Based on Rep-PCR and Multilocus Sequence Analysis. J Plant Pathol Microbiol 6: 317. doi:10.4172/2157-7471.1000317

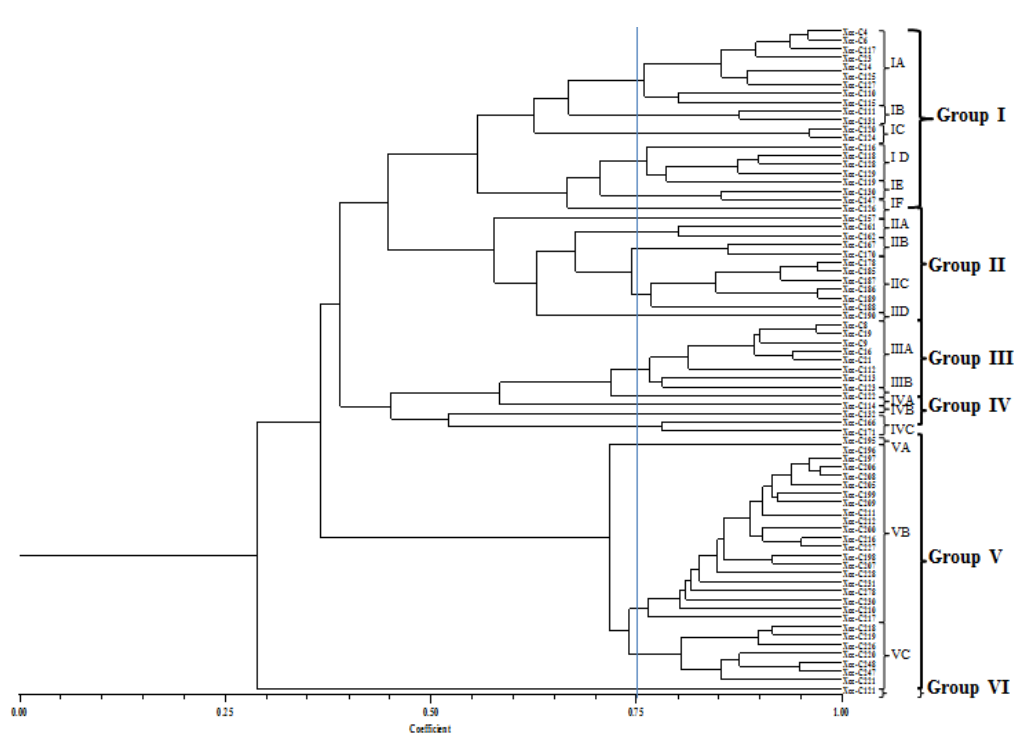

Figure 2: Combined Dendrogram representing genetic relationships between the strains of $X$. campestris pv. campestris based on BOX, ERIC and REP-PCR fingerprints. Similarity (\%) between patterns was calculated by using the Jaccard's coefficient. The data were sorted by using the UPGMA clustering method.

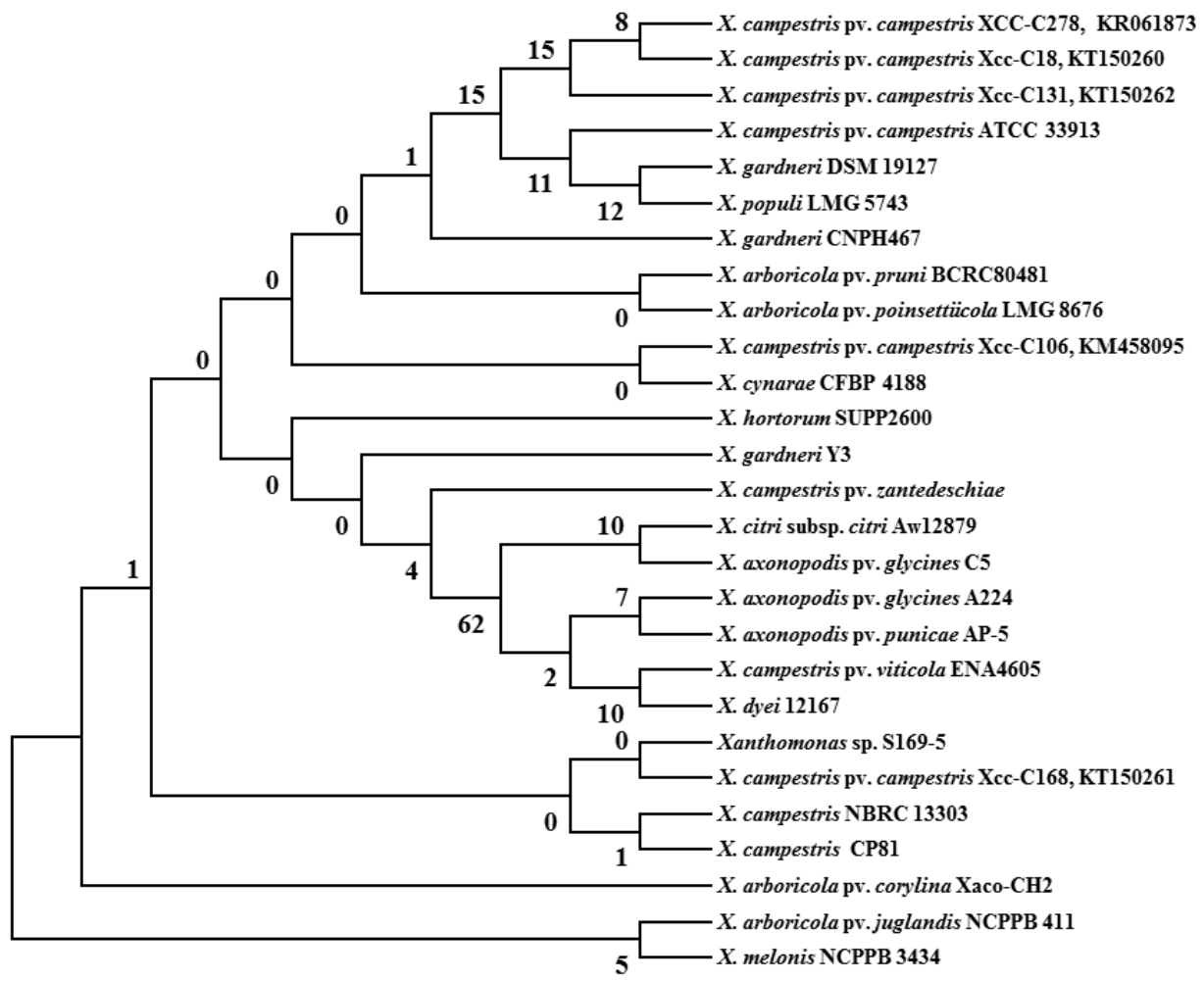

Figure 3: Phylogenetic tree of $16 \mathrm{~S}$ rRNA sequences of 5 Indian isolates of $X$. campestris pv. campestris and 22 nucleotide sequences data obtained from NCBI database. The evolutionary history was inferred using the Neighbor-Joining method by using MEGA 6.0.

showed very clear differentiation at the pathovar level. However, we could not find any relation of races with sequence similarity of the efP gene.

Phylogenetic sequevar analysis of $h r p F$ genes demonstrated that the 5 representative Indian isolates formed a distinct cluster from the strains of Xcc from other countries, obtained from NCBI database. Out of 8 strains of Xcc and one strain of $X$. campestris pv. raphani, 5 were clustered in Group 1 and 3 strains in Group 2 (Figure 5). The highly similar sequences of Xcc B100 and Xcc 8004 taken from NCBI Genbank were clustered in Group 2. The sequence from the five representative Indian Xcc strains showed more than $90 \%$ homology with each other and also with Xcc strain ATCC33913 and X. campetris pv. raphani 756C in group 1 (Figure 5). 
Citation: Rathaur PS, Singh D, Raghuwanshi R, Yadava DK (2015) Pathogenic and Genetic Characterization of Xanthomonas campestris Pv. campestris Races Based on Rep-PCR and Multilocus Sequence Analysis. J Plant Pathol Microbiol 6: 317. doi:10.4172/2157-7471.1000317

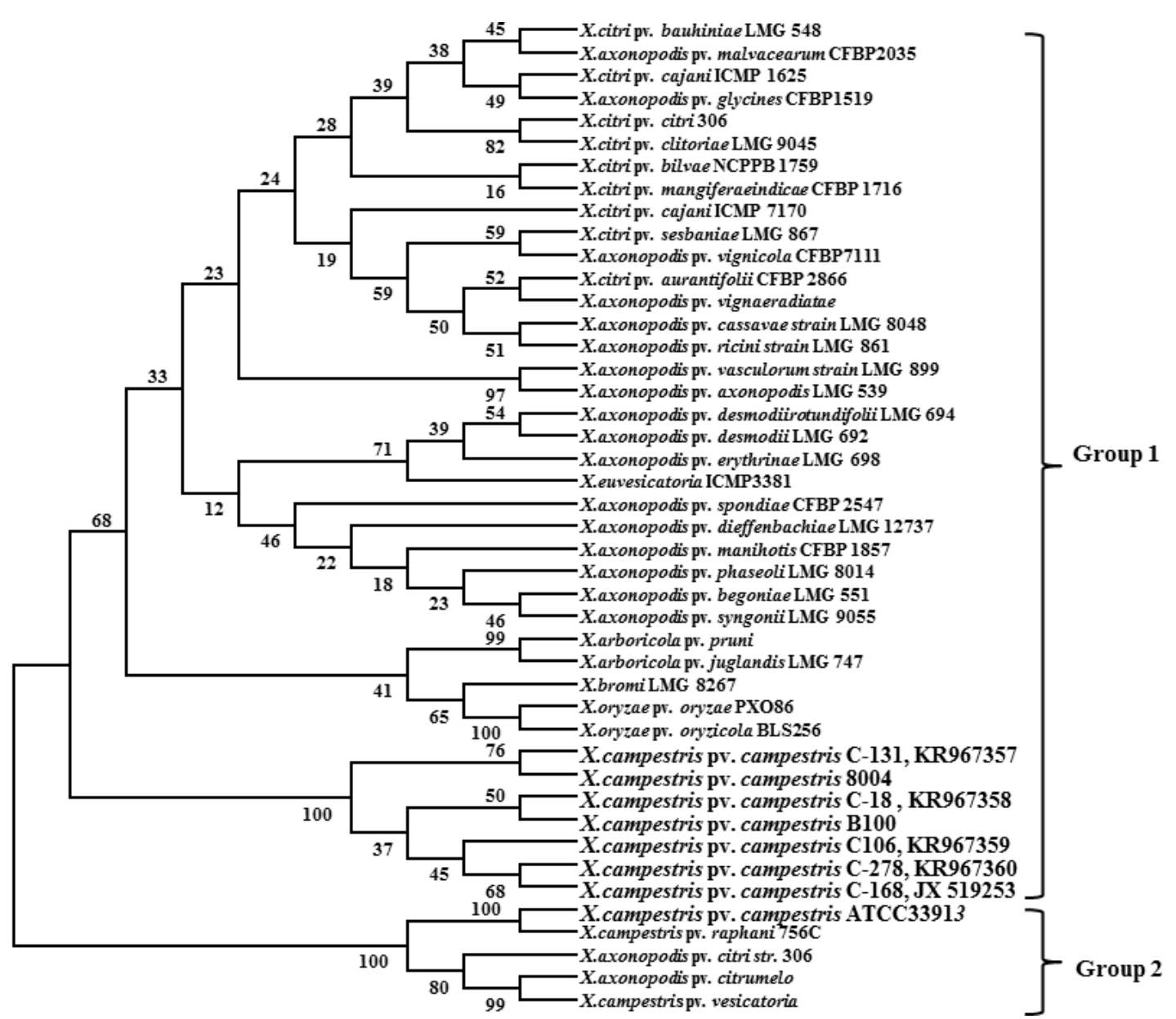

Figure 4: Phylogenetic tree of efP gene sequences of 5 Indian isolates of $X$. campestris pv. campestris and 44 nucleotide sequences data obtained from NCBI database. The evolutionary history was inferred using the Neighbor-Joining method by using MEGA 6.0.

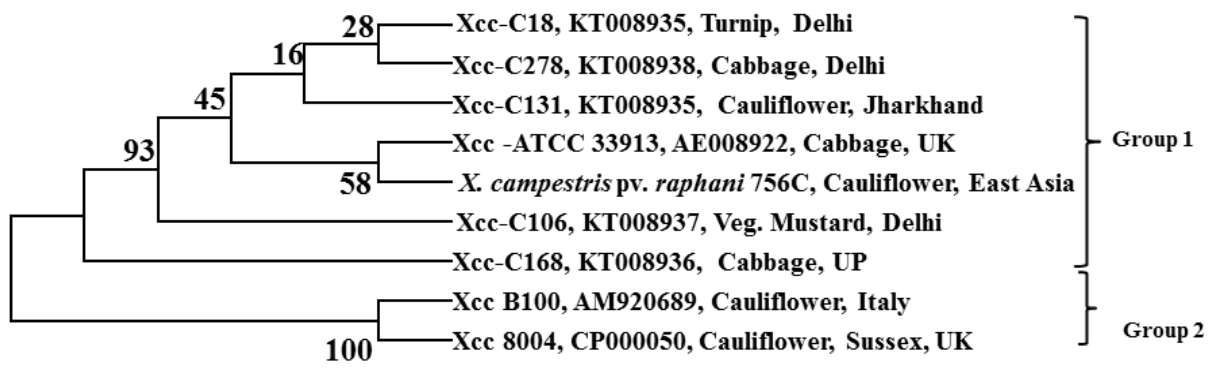

Figure 5: Taxonomic analysis of partial $h r p F$ gene sequences of $X$. campestris pv. campestris strains using neighbor-joining phylogenetic distribution. The dandrogram was generated by Mega (version 6.06) software using UPGMA mean applied to the distance matrix of nucleotide differences. Number at branch point indicates percent bootstrap support for 1000 interactions.

\section{Discussion}

Black rot disease is widely distributed in all agro-climatic regions of India. The isolates of Xcc were collected from 12 agro-climatic regions under 18 states of India from 8 crucifer crops. In the present studies, black rot producing isolates of Xcc were characterized by pathogenicity test and advanced technique like PCR based molecular technique using 16srRNA, efP, hrp gene $[13,14]$ which is to highly conserved to enable differentiation of the pathovars [20]). All the isolates were identical in classical tests and produced typical black rot disease symptom as
$\mathrm{V}$ - shaped yellowing and necrosis of tissue and blackening of veins. Crucifers especially cole crops, tubers and oliferous crops belonging to Brassica and Raphanus species are affected by black rot incited by Xcc.

In the present work, race characterization had been done in India. Presently, nine races of Xcc are known in the world and among them races 1 and 4 are predominant [18], which is corroborated by our findings. Race typing of 51 strains of Xcc by Vicente [28] found three races $(1,4$ and 6$)$ in Portugal. While, Jensen et al. [1] reported races 1, 3, 4, 5, 6 and 7 in cabbage from Nepal and among them 1, 4 
and 6 were the most common. In our study also race 1 was found to be predominant followed by race 4 in $B$. oleracea cultivars in the all agro-climatic regions in India, whereas race 6 was found only once on cabbage in Delhi state. In contrast Lema et al. [29] isolated race 6 from B. rapa. However, races $2,3,5,7$, and 9 were not found in India. In the present study, all isolates of Xcc produced typical V- shaped symptoms of black rot disease on the crucifer crops.

In recent studies, using defined races, race specific resistance in different collections of B. oleracea, B. rapa and B. napus have been identified [30]. All the tested cultivars of crucifers were challenged with concentrated suspensions of Xcc, using leaf clipping of young plants to establish the extent and type of resistance in all tested species of Brassica and R. sativus which clearly favours the pathogen and the rapid development of symptoms. The black rot symptoms appeared within six days in susceptible cultivars, while symptom development was delayed up to15 days in resistant cultivars.

Genetic diversity of plant pathogenic bacteria has been studied by DNA based approaches to generate evidence of genome plasticity, ecological distribution, dispersal and evolution. Knowledge of the existence of genetic variability in the pathogen population is important for plant breeding and consequently in crop improvement program. For genomic variability, rep-PCR fingerprinting using primer sets (BOX, REP and ERIC) are highly conserved repetitive sequences [31], showed different banding pattern among Xcc isolates of different crucifer hosts in India. In our studies, similar levels of resolution were observed compared with previous rep-PCR studies of Xanthomonas $[1,2,32]$. Rep-PCR has proven to be a reliable fingerprinting tool reinforcing its applicability to track Xcc strains in culture collections and for quality control of commercial inoculants. It is a rapid, low-cost, and reliable method that has been extensively used to assess the genetic diversity of Xcc strains $[2,29]$ and has potential to determine the diversity within Xcc similar to that of other techniques such as pulsefield gel electrophoresis or amplified fragment length polymorphism. Moreover, the method is adequate for grouping or defining species or even pathovars and strains [29]. Rep-PCR has also been used successfully to characterise a large number of bacteria and differentiated closely related strains of bacteria [1,31]. The data obtained from the pathogenicity and genetic diversity analysis in this study confirmed previous findings describing the heterogeneity within Xcc strains. The strains within the groups revealed complex but polymorphic bands resulting in grouping of closely related strains based on fingerprinting patterns. However, the strains recovered from samples from the same host and states/agro-climatic region with the same race did not fall into one group but into subgroups spread over the dendrogram. Similar results were also reported by Jensen et al. [1] from Nepal, Valverde et al. [10] from Israel and Zaccardelli et al. [9] from Italy. Although, a previous study had demonstrated a correlation of races with their geographical origin, [33] but we found that the strains of Xcc could not be separated on the basis of races and their geographical origin. Here, three different genes were used separately to study genetic diversity of five strains of Xcc representing races 1,4 and 6. The results from $16 \mathrm{~S}$ rRNA and $h r p \mathrm{~F}$ gene analyses revealed diversity at the genus and species level and efP gene can be used to differentiate at the pathovar level. None of these three genes are able to differentiate at the race level. This study revealed the existence of variations within Indian isolates of Xcc.

The evolutionary processes occurring in the pathogen and how pathogen populations adapt to changes in host resistance or susceptibility are equally important in the evolutionary arms race. Race study is depend on simpler gene-for-gene model has been proposed by $\mathrm{He}$ et al. [34] based on the interactions between Xcc isolates and cultivars of Brassica (B. juncea, B. oleracea, B. rapa), radish (Raphanus sativus) and pepper (Capsicum annuum). Arms races are ultimately determined at the phenotypic level, but examining individual antagonistic genetic systems, such as resistance (R) genes and their corresponding avirulence (Avr) genes, and cell-wall attacking enzymes and their inhibitors, can provide new insights. In our study we found three races, which are distinguished based pathogenic reactions on the hosts and they are directly related to effector proteins. Sometime very similar results were found between plant and human pathogenic bacteria. A current study about the evolution linkage between human pathogenic bacteria and Xanthomonas AvrRxo1-ORF1 has been reported by Qian Han et al. [35]. However, evolution of races in Xcc is required further study. Evolutionary analysis can suggest how arms races are produced, and to what extent genetic variation are shaped by co-evolutionary outcomes.

\section{Conclusion}

Seventy five Xcc isolates were characterized into three races, i.e., races 1, 4 and 6. Pathogenic study will helpful to develop resistant cultivar of crucifers. This study revealed the existence of variations within Indian isolates of Xcc. In this study, although some isolates obtained from the same source produced similar BOX, ERIC, REPPCR profiles, other strains showed different profiles despite belonging to the same race. On the other hand, some isolates had similar profiles despite belonging to different races. This suggests that rep PCR can be used for rapid initial screening of isolates to select non-identical ones for further analysis, including race typing. However, our results showed that rep-PCR, 16S rRNA, hrpF and ef P sequence analysis were not suitable for differentiation of Xcc races, presumably because the races are dependent on which different combinations of avirulence genes in the pathogen population will be recognised by different combinations of resistance genes in the host (the 'gene for gene' hypothesis).

\section{Acknowledgements}

The authors are thankful to SERB, Department of Science and Technology, New Delhi for providing financial support under project entitled "Characterization and identification of Xanthomonas campestris pv. campestris races causing black rot disease of crucifers" to conduct the experiments. The authors are also thankfu to Heads, Division of Plant Pathology, IARI, New Delhi and Department of Botany, Mahila Mahavidyalya, Banaras Hindu University, Varanasi-221005 (India) for their keen interest and help throughout the course of these investigations.

\section{References}

1. Jensen BD, Vicente JG, Manandhar HK, Roberts SJ (2010) Occurrence and diversity of Xanthomonas campestris pv. campestris in vegetable brassica fields in Nepal. Plant Disease 94: 298-305

2. Singh D, Dhar S, Yadava DK (2011) Genetic and pathogenic variability of Indian strains of Xanthomonas campestris pv. campestris causing black rot disease in crucifers. Curr Microbiol 63: 551-560.

3. Kamoun S, Kamdar HV, Tola E, Kado Cl (1992) Incompatible interactions between crucifers and Xanthomonas campestris involve a vascular hypersensitive response: role of the hrpx locus. Mol. Plant Microbe Interact 5: 22-23.

4. Ignatov A, Hidam K, Kuginuki Y (1999) Pathotypes of Xanthomonas campestris pv. campestris in Japan. Acta Phytopathologica et Entomologica Hungarica 34: $177-182$

5. Taylor JD, Conway J, Roberts SJ, Astley D, Vicente JG (2002) Sources and Origin of Resistance to Xanthomonas campestris pv. campestris in Brassica Genomes. Phytopathology 92: 105-111.

6. Vicente JG, Taylor JD, Sharpe AG, Parkin IA, Lydiate DJ, et al. (2002) Inheritance of Race-Specific Resistance to Xanthomonas campestris pv. campestris in Brassica Genomes. Phytopathology 92: 1134-1141. 
Citation: Rathaur PS, Singh D, Raghuwanshi R, Yadava DK (2015) Pathogenic and Genetic Characterization of Xanthomonas campestris Pv. campestris Races Based on Rep-PCR and Multilocus Sequence Analysis. J Plant Pathol Microbiol 6: 317. doi:10.4172/2157-7471.1000317

7. Louws FJ, Fulbright DW, Stephens CT, DeBruijn FJ (1994) Specific genomic fingerprints of phytopathogenic Xanthomonas and Pseudomonas pathovars and strains generated with repetitive sequences and PCR. Appl Environ Microbiol 60: 2286-2295.

8. Gonçalves ER, Rosato YB (2002) Phylogenetic analysis of Xanthomonas species based upon $16 \mathrm{~S}-23 \mathrm{~S}$ rDNA intergenic spacer sequences. Int J Syst Evol Microbiol 52: 355-361.

9. Zaccardelli M, Francesco C, Annalisa S, Massimo M (2007) Detection and identification of the crucifer pathogen, Xanthomonas campestris pv. campestris, by PCR amplification of the conserved Hrp/type III secretion system gene hrc C. Euro J Plant Pathol 118:299-306.

10. Valverde A, Hubert T, Stolov A, Dagar A, Kopelowitz J, et al. (2007) Assessment of genetic diversity of Xanthomonas campestris pv. campestris isolates from Israel by various DNA fingerprinting techniques. Plant Pathology 56: 17-25.

11. Higgins CF, Ames GF, Barnes WM, Clement JM, Hofnung M (1982) A novel intercistronic regulatory element of prokaryotic operons. Nature 298: 760-762.

12. da Silva AC, Ferro JA, Reinach FC, Farah CS, Furlan LR, et al. (2002) Comparison of the genomes of two Xanthomonas pathogens with differing host specificities. Nature 417: 459-463.

13. Berg T, Tesoriero L, Hailstones DL (2006) A multiplex real-time PCR assay for detection of Xanthomonas campestris from brassicas. Lett Appl Microbio 42: 624-630.

14. Singh D, Dhar S (2011) Bio-PCR based diagnosis of Xanthomonas campestris pv. campestris in black rot of infected leaves of crucifers. Indian Phytopathology 64: 7-11.

15. Aoki H, Dekany K, Adams SL, Ganoza MC (1997) The gene encoding the elongation factor $\mathrm{P}$ protein is essential for viability and is required for protein synthesis. J Biol Chem 272: 32254-32259.

16. Achtman M, Azuma T, Berg DE, Ito Y, Morelli G, et al. (1999) Recombination and clonal groupings within Helicobacter pylori from different geographical regions. Mol Microbiol 32: 459-470.

17. Schaad NW, Jones J B, Lacy GH (2001) Xanthomonas. Laboratory guide for identification of plant-pathogenic bacteria, American Phytopathological Society Press, St. Paul.

18. Vicente JG, Conway J, Roberts SJ, Taylor JD (2001) Identification and Origin of Xanthomonas campestris pv. campestris Races and Related Pathovars. Phytopathology 91: 492-499.

19. Murray MG, Thompson WF (1980) Rapid isolation of high molecular weight plant DNA. Nucleic Acids Res 8: 4321-4325.

20. Singh D, Raghavendra BT, Rathaur PS, Singh H, Raghuwanshi R, et al. (2014) Detection of black rot disease causing pathogen Xanthomonas campestris pv. campestris by bio-PCR from seeds and plant parts of cole crops. Seed Sci Technol 42: 36-46.

21. Rohlf FJ (2000) NTSYS-pc: Numerical Taxonomy and Multivariate Analysis System, Version 2.2. Exeter Software. Setauket, New York.
22. Thompson JD, Gibson TJ, Plewniak F, Jeanmougin F, Higgins DG (1997) The clustal $X$ windows interface: flexible strategies for multiple sequence alignment aided by quality analysis tools. Nucleic Acids Res 25: 4876-7882

23. Tamura K, Stecher G, Peterson D, Filipski A, Kumar S (2013) MEGA6 Molecular Evolutionary Genetics Analysis version 6.0. Mol Biol Evol 30: 27252729 .

24. Saitou N, Nei M (1987) The neighbor-joining method: a new method for reconstructing phylogenetic trees. Mol Biol Evol 4: 406-425.

25. Felsenstein J (1985) Confidence limits on phylogenies: an approach using the bootstrap. Evolution 39: 783-791.

26. Hauben L, Vauterin L, Swings J, Moore ER (1997) Comparison of $16 \mathrm{~S}$ ribosomal DNA sequences of all Xanthomonas species. Int J Syst Bacterio 47: $328-335$

27. Popovic T, Josic D, Starovic M, Milovanovic $P$, Dolovac $N$, et al. (2013) Phenotypic and genotypic characterization of Xanthomonas campestris strains isolated from cabbage, kale and broccoli. Arch Biol Sci Belgrade 65: 585-593

28. Vicente JG (2004) A podridaonegra das cruciferas. (Lopes, G., ed) Alcobaca: COTHN Centro Operativo e Tecnologico Hortofruticola.

29. Lema M, Cartea ME, Sotelo T, Velasco P, Soengas $P$ (2012) Discrimination of Xanthomonas campestris pv. campestris races among strains from northwestern Spain by Brassica spp. genotypes and rep-PCR. Eur J Plant Pathol 133: 159-169.

30. Ignatov A, Kuginuki Y, Hida K (2000) Distribution and inheritance of racespecific resistance to Xanthomonas campestris pv.campestris in Brassica rapa and B. napus. J Russian Phytopathol Soc 1: 89-94

31. Versalovic J, Koeuth T, Lupski JR (1991) Distribution of repetitive DNA sequences in eubacteria and application to fingerprinting of bacterial genomes. Nucleic Acids Res 19: 6823-6831.

32. Vicente JG, Everett B, Roberts SJ (2006) Identification of Isolates that Cause a Leaf Spot Disease of Brassicas as Xanthomonas campestris pv. raphani and Pathogenic and Genetic Comparison with Related Pathovars. Phytopathology 96: 735-745

33. Massimo Z, Francesco C, Annalisa S, Massimo M (2007) Detection and identification of the crucifer pathogen, Xanthomonas campestris pv. campestris, by PCR amplification of the conserved Hrp/ type III secretion system gene hrc C. Eur J Plant Pathol 118: 299-306.

34. He YQ, Zhang L, Jiang BL, Zhang ZC, Xu RQ et al. (2007) Comparative and functional genomics reveals genetic diversity and determinants of hos specificity among reference strains and a large collection of Chinese isolates of the phytopathogen Xanthomonas campestris pv. campestris. Genome Biology 8: R218.

35. Han Q, Zhou C, Wu S, Liu Y, Triplett L, et al. (2015) Crystal Structure of Xanthomonas AvrRxo1-ORF1, a Type III Effector with a Polynucleotide Kinase Domain, and Its Interactor AvrRxo1-ORF2. Structure 23: 1900-1909. 